\title{
Dependency of Tharu communities on wild plants: A case study of Shankarpur, Kanchanpur district
}

\begin{abstract}
S. Bhattarai ${ }^{1}$, B. Pant ${ }^{2}$, C. P. Upadhyaya ${ }^{3}$
Tharu communities are rich in indigenous knowledge of managing environmental resources and coping with environmental stress. The dependency pattern of these communities on wild plants and their role in conservation of wild plants should be identified and explored. This study was carried out with the purpose of assessing dependency pattern of these communities on wild plants and understanding their attitude as well as role in conservation. Both qualitative and quantitative data were collected from concerned stakeholders. Primary data were supplemented and verified from key informants, field observation and secondary sources. Among the four categories of dependency, majority of the respondents were found under category dependent followed by most dependent and somewhat dependent, respectively, but minority of them were found under category not dependent. Almost all of the respondents were found to have played some role in wild plant conservation. Their attitude towards forest and resource conservation was positive, yet they were not satisfied with the traditional mechanism of forest conservation. The traditional approach of managing forest should, therefore, be modified and a new community-oriented approach should be promoted.
\end{abstract}

Key words: Tharu, wild plants, dependency, role, attitude, conservation

$\mathbf{N}$ epal is well recognized internationally for forest management. However, passive participation of community in decision making for the management of conservation areas has brought serious implication to the livelihood and cultural dynamics of the local people (McLean and Straede, 2003). Moreover, population pressures, particularly the expansion of urban areas and agriculture, has caused conservation areas to become islands or increasingly fragmented habitats (Molnar, 2006). Existing provisions and arrangements deprive the people living outside the national parks and reserves from using forest products which they had been doing traditionally, much before the parks or reserves were created (Dhungel and Adhikari, 1994). Tharu are the disadvantaged groups and even the urbanization process has not made much impact in their livelihoods (Sharma, 2006). The indigenous skills, technologies, and expertise of the Tharus are ageold, which they are still capitalizing as one of their coping strategies.
Shuklaphanta Wildlife Reserve (SWR), covering an area of $305 \mathrm{~km}^{2}$, was established in 1976 to preserve the habitat of the swamp deer, Bengal tiger and a variety of flora and fauna. The buffer zone area of SWR which is spread over $243.5 \mathrm{~km}^{2}$, covers 11 Village Development Committes (VDCs) and one municipality. It constitutes a unique inheritance that supports both marginalized indigenous tribes and endangered flagship animals (DNPWC, 2003). It consists of Laljhadi Corridor linking Dudwa National Park of India and Shuklaphanta Wildlife Reserve of Nepal (CBS, 2003).

The indigenous Tharu communities have been living in the area even before the establishment of SWR. Nowadays, these Tharu communities are facing complex problems and threats to their livelihood. Not only are they confronted with dispossession of their lands and resources, and physical persecution, but they are also faced with the loss of their collective

\footnotetext{
${ }^{1}$ University of Copenhagen, Denmark, Email:- bhattarai.sushma@gmail.com

${ }^{2}$ International Centre for Integrated Mountain Development, Nepal

${ }^{3}$ Institute of Forestry, Pokhara Campus, Pokhara, Nepal
} 
knowledge developed through the ages. Traditional knowledge of medicinal plants and crops is being invaded by multinational companies, while traditional songs and designs are being commercialized for tourism industry. The issue of indigenous cultural property rights is becoming more and more urgent for these indigenous people (Bengwayan, 2003). Therefore, this study endeavoured to assess the sociocultural association and dependency of Tharu community on plant resources and, identify the attitude and critical role of the community in conservation of the wild food crops and plants.

\section{Materials and methods}

The study was conducted among indigenous Tharu communities of Shankarpur VDC of Kanchanpur district. The VDC comprises about 720 households, with a total population of 6,538 (male $51.15 \%$ and female 48.85\%) (CBS, 2003). This area has long been marginalized due to its remoteness. The study was supported by different social analysis tools. Both qualitative and quantitative data were collected from concerned stakeholders. One hundred and seventeen households, representing $20 \%$ sample from each nine wards, were taken purposively. Various PRA tools were used to obtain primary data. The collected data were supplemented and verified from key informants, field observation and secondary sources.

At first, harvest frequency of each type of resource was calculated. Based on harvest frequency, resources were assigned importance values. The weight of seven to one score was applied in descending order; seven was assigned to the resource having the highest frequency. The weighted scores of types of resources harvested in a household were summed to calculate a resource use score that could theoretically range from 0 to 28. The higher the score, the more dependent were respondents. Based on an equal interval, the resource use score was categorized into four categories: not dependent, somewhat dependent, dependent, and most dependent (Baral, 2005). To measure a relationship between resource use score and quantitative socio-economic variables,

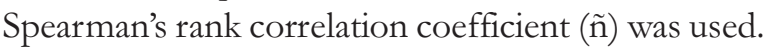

For attitude assessment, a series of statements were presented and respondents were asked to agree or disagree. If the respondent agreed with the statement one point was given, otherwise no point was given.
The reverse was true for a negative statement. The scores of all statements were summed to derive an attitude score that could theoretically range from zero to six. The higher the attitude score, the more favourable attitude the respondents had towards conservation. Regression model taking the conservation attitude, score as dependent variable; and demographic, socio-economic and resource use score as independent variables. All categorical independent variables in the model were recorded as dummy variables, each with two categories: 'yes' and 'no'. The selected indicators were plotted in radial graphs. To standardize i.e., bringing into unit less factor, the scales for each assets were measured out of ten. This involved, for each indicator, assuming the maximum variable as 100 , dividing the maximum value by ten to give appropriate standardizing factor, and then multiplying each value of the indicator by this factor. For the indicator, average value of each capital was determined and plotted in the radial graph.

\section{Results and discussion}

\section{Socio-economic features}

There were two types of Tharu groups: Rana and Chaudhary. Majority of the respondents were Rana and the minority group was Chaudhary. Among these, most were male respondents. Regarding age group, the majority of the respondents were from middle-aged (36-54) class. Less than a half of the population was found to be illiterate, followed by primary and secondary education, while some had college education. The average family size of 9.76 per household of Shankapur was found to be remarkably higher than the national average of 5.6 persons and district average of 6.2 (Pant, 2007).

Agriculture is the prime source of income for Tharu people. Rice, wheat, mustard are the main food crops. According to the respondents, they get enough food from their agricultural land. The large land owners sell the surplus food whereas small land owners do not even get enough food for a full year.

Majority of the respondents were found to be middle class land owners ( 0.5 to 2 hectare of land) followed by large (more than 2 hectare) and small land owners (less than 0.5 hectare), respectively. The comparison of land and income inequality between Chaudhary and Rana Tharu revealed that there exist higher inequalities among Chaudhary than Rana. The average 
income per household of both Rana (\$1368, converted at the rate of 73.27 Nepalese rupees for 1 US dollar) and Chaudhary (\$12158) was found to be higher than the national average (\$1093) (CBS, 2004).

\section{Dependency assessment \\ Dependency on fuelwood}

The analysis revealed that majority of the respondents used firewood for cooking and other purposes. Majority of respondents used simple mud stove $(93.16 \%), 5.13 \%$ of respondents used biogas and $1.71 \%$ of respondents used improved stove.

Ten major species; Shorea robusta, Terminalia tomentosa, Adina cordifolia, Schleichera oleosa, Syzygium cumini, Trewia nudiflora, Syzygium cerasoides, Zizyphus mouritiana, Mallotus phillippensis and Bombax ceiba, were used as fuelwood. Majority of the respondents (94.87\%) used protected Laljhadi forest, as a main source of fuelwood. Besides this, 5.13\% depended on buffer zone for their fuel wood needs. Furthermore, analysis among the respondents consuming fuelwood showed that $78.63 \%$ of respondents got sufficient fuelwood while $21.37 \%$ of them did not get sufficient fuelwood. This is significant at 0.01 level of significance. The study revealed that among the respondents having insufficient fuelwood, majority $(68 \%)$ believed controlled collection of fuelwood from the forest as the best technique to fulfill the demand. This was followed by $24 \%$ of respondents agreeing on husk made stove and improved stove. Only $8 \%$ of respondent were found in favour of biogas.

\section{Dependency on fodder}

The common types of livestock found in the study area included: cattle, buffalo, goat/sheep, and pig. The farm animals were kept mainly for manure, milk and traction. As the values of different livestock and their impacts on natural resources vary, the number of livestock per household was expressed using the Livestock Size Unit (LSU).

The average LSU of cow, ox, she-buffalo, he-buffalo, goat and pig was $0.41,1.61,0.64,0.73,0.76$, and 0.36 , respectively. Cows were the most preferred livestock than others. LSU per household ranged from 0 to 17.35 .
As there was no grazing land within the village and nearby forest was being protected by the forest protection committee, majority $(56.64 \%)$ of the respondents opted for stall feeding the livestock. This was followed by $30.97 \%$ respondents practicing both free grazing and stall feeding. Only $12.39 \%$ respondents were found adopting free grazing only. Those respondents grazed their livestock illegally inside the forest. Dalbergia sissoo, Dendrocalamus strictus, Baubinia purpurea, Cynodon dactylon, Impereta cylindrica, Saccharum spontaneum, Ficus glumerata, Trewia nudiflora, Holarrbena pubescens, and Floscopa scandens were identified the major fodder species. Regarding the source of fodder, $54.87 \%$ respondents claimed their own land as the main source of fodder for their livestock, followed by $40.71 \%$ and $4.42 \%$ respondents claiming protected forest and buffer zone forest as sources of fodder, respectively.

Regarding sufficiency of fodder, a greater portion, $59.3 \%$ of the respondents replied that they had shortage of fodder whereas $40.7 \%$ replied that they had sufficient fodder supply (chi-square value of 3.90 and $\mathrm{p}$-value of 0.048$)$. To meet the fodder deficiency problem, majority $(41.79 \%)$ respondents suggested plantation of improved grass species on private land as the best alternative, followed by $28.36 \%$ suggesting to reduce the number of livestock, $20.90 \%$ to allow free grazing in the forest and $8.96 \%$ suggesting using straw, husk and other feeding materials as alternative strategies. Non-parametric correlation between land size and LSU showed that there is positive correlation (coefficient $=.044, \mathrm{p}=.000$ ) between land size and LSU per household which signifies that large land owners kept more number of livestock than small land owners.

\section{Dependency on wild food}

Most of the respondents in the study area consumed wild food. Tharu people have been using wild food since long time in different forms. Wild food plants are basically considered as famine food, the consumption of which is linked to times of scarcity (Santayana et al., 2005). Most species were consumed in raw form with no preparation. The collection of these wild foods varies according to the season and their availability. The majority of wild food plants were valued for their green leaves and young shoots and used as vegetable, which were gathered vigorously at the start of monsoon season. 
Study revealed that $52.80 \%$ respondents consumed wild plants as vegetables followed by $28.20 \%$ consuming mushroom, $15.35 \%$ and $3.65 \%$ respondents consuming wild foods in the form of fruits and roots, respectively. Among different types of wild plants taken as food, ten major plants were Trewia nudiflora, Ganoderma spp. Aegle marmelos, Baubinia purpurea, Cannabis sativa, Emblica officinalis, Syzygium cumini, Ophioglossum nudicaule, Morus alba, and Ficus bengalensis. Majority (67.3\%) of the respondents, gathered wild food in the monsoon season because at that period vegetables found in home garden were insufficient to support their family. As far as the purpose of collecting wild food is concerned, $85 \%$ respondents said because of taste, followed by $9.40 \%$ respondents to earn money, and the rest $5.13 \%$ saying due to unavailability of other alternatives. Most of the respondents liked the taste of wild food and they collected only for their own use while 11 respondents collected wild food mainly for selling . Among those respondents who sold wild plants, $81.82 \%$ did so because of low income status and $18.18 \%$ because of surplus.

\section{Dependency on medicinal plants}

Since Tharu people believe in traditional knowledge, they first try to cure their disease by consulting guruwa (the local faith heater) in the beginning. If this fails, they go for modern medical treatment. The analysis revealed that the local people did not have sound knowledge about medicinal plants. Information about the identification and distribution of these plants was purely confined to the guruwas and their family. With passage of time and the advancement of technology, Tharu people are now using both allopathic medicine and traditional methods. Majority of the respondents i.e. $88.03 \%$ used both traditional and allopathic medicine while $6.84 \%$ and $5.13 \%$ respondents used only allopathic medicine and traditional medicine, respectively. To utilize these wild plants for their daily subsistence needs, Tharu communities have travelled mean distance of 2.56 $\pm 1.67 \mathrm{~km}$, ranging from $0.1 \mathrm{~km}$ to $8 \mathrm{~km}$. The list of major medicinal plants are: Adina cordifolia,

Viscum articulatum, Emblica officinalis, Terminalia chebula, Terminalia belerica, Mallotus philippinensis, Datura metel, Piper longum, Calotropis gigantea, Aegle marmelos.

\section{Resource use patterns and dependency}

Fuelwood is the main source of energy in the study area. Local people use thatch as roofing material, and grasses and fodder as livestock feed. Mushrooms, fruits and vegetables are supplementary to staple diet. Green leaves are used to make leaf plates and in religious ceremonies. Dry leaves are harvested to use as bedding material for livestock and which is later on composted. Mainly seven types of resources were extracted from the forest (Fig.1). Majority of the respondents harvest fuelwood having weighted factor of 9.74 followed by wild food (9.49), thatch (5.47), timber (5.38), leaf litter (5.21), fodder (4.36) and medicinal plants (1.88).

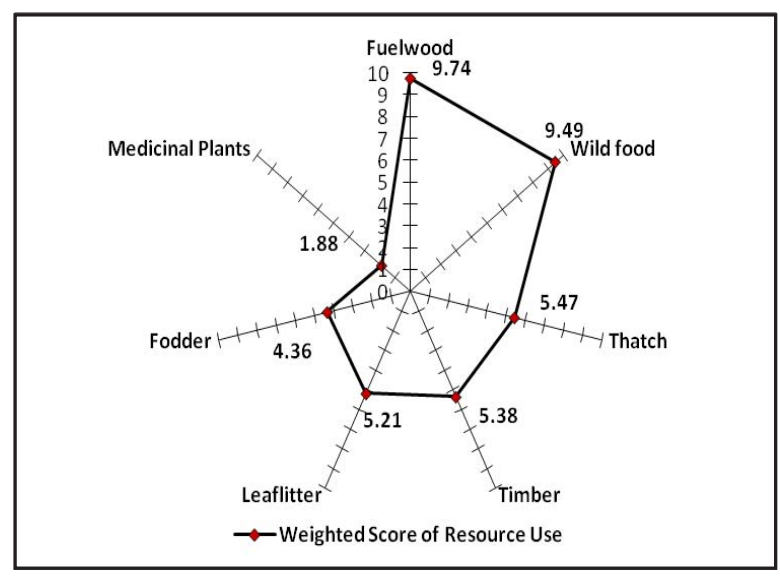

Fig 1: Resource use score of respondents

The non-parametric correlation of continuous variables with the resource use score showed that there was a significant negative correlation between the resource use score and total land $(p=0.02)$, resource use score and total income $(\mathrm{p}=0.01)$ and negative correlation between resource use score and education of the respondents $(p=0.07)$. Based on resource use score, $41.03 \%$ respondents belonged to most dependent, $48.72 \%$ to dependent, $8.55 \%$ to somewhat dependent and only $(1.71 \%$ belonged to not dependent.

\section{Trend and status of sustainable resource use}

Apart from the findings of household survey, selected indicators such as dependency on forest resources, alternative energy use, forest promotion activities, erosion and landslides, importance of wild plants, difficulties in use, and income from wild plant sale (Fig. 2) were used to assess the trend and status of sustainable resource use. The study revealed positive 
impacts in terms of alternative energy use and forest promotion activities. However, it also indicated that status of erosion and landslides, importance of wild plants, resource use difficulties, and income from wild plant sale had decreased.

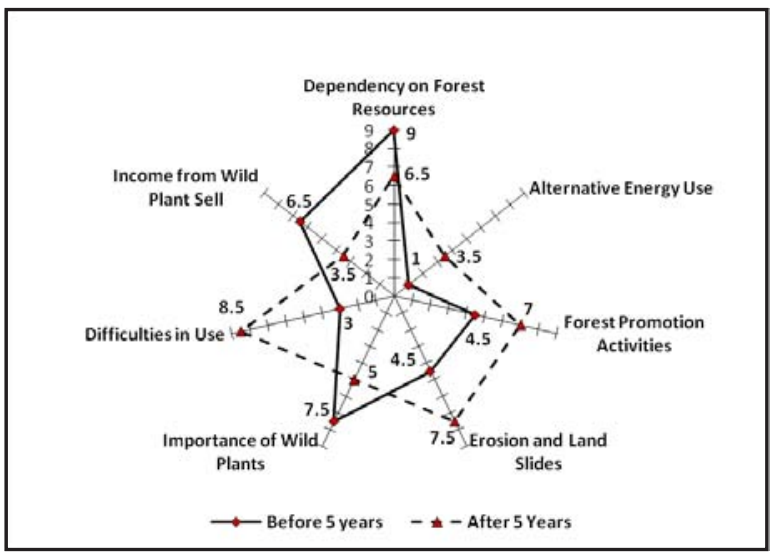

Fig 2: Status of sustainable resource use

The causes of the positive change are: shift in resource use pattern for subsistence livelihood; the adoption of alternative way to earn their requirements; increase in awareness level with the passage of time; and ban on free access to the forest. The reason behind negative effect were increase in deforestation; lack of sound knowledge regarding the identification and distribution among youths; decrease in quantity of wild plants availability inside the forest.

\section{Knowledge}

Tharus are tribal people whose social cultural and economic conditions distinguish them from other communities. A number of local practices and technologies are in existence among the Tharu communities for natural resources management. These have been developed over the years through accumulated knowledge, experience and testing. Respondents were found to have significant knowledge on biodiversity (Table 1). The study revealed that the respondents did not have sound knowledge about medicinal plants and the distribution of rare wild plants (type of species, their sources and use).

\section{Conservation attitudes}

Six questions were asked to the respondents regarding conservation of wild foods, forest conservation, medicinal plants, prohibition of deforestation, necessity of forest, and continuity of traditional forest conservation practices. The overall attitude towards nature conservation was found to be positive. It is very important to note that this asset of local acceptance should be considered in any kind of management intermention.

\section{Role}

Due to the awareness of the deteriorating condition of Laljhad forest, people of Shankarpur VDC have strictly protected their forest by forming a forest protection committee. Most of the households are involved in the protection of the forest mainly by guarding the forest. The main problem of the deterioration of the forest was due to illegal cutting of trees and transportation to neighbouring VDC. Thus, they guard the forest day and night. The survey showed that various efforts had been done by the communities in order to conserve wild plants. Apart from guarding, other efforts included plantation of wild plants, forest protection against fire, reporting of illegal felling of trees and others (protection of NTFPs, etc). As many as $95.72 \%$ of respondents were involved in these different activities whereas $2.56 \%$ didn't participate in any of the above activities and $1.71 \%$ did not respond. Among the respondents performing significant role, majority $(41.03 \%)$ were found to be involved in guarding the forest, $20.51 \%$ in reporting about illegal tree felling, 20.51\% in protecting from forest fire and $15.38 \%$ in plantation.

Table 1: Knowledge about biodiversity

\begin{tabular}{lllllll}
\hline SN & Statements & Yes (\%) & No (\%) & X2 & p & S/NS \\
\hline 1 & Knowledge about biodiversity & 58.97 & 41.03 & $3.77^{*}$ & 0.05 & $\mathrm{~S}$ \\
2 & Importance of wild plants & 70.94 & 29.06 & $20.52^{*}$ & 0.00 & $\mathrm{~S}$ \\
3 & Knowledge about medicinal plants & 42.74 & 57.26 & 2.47 & 0.12 & $\mathrm{NS}$ \\
4 & Distribution of rare wild plants & 48.72 & 51.28 & 0.08 & 0.78 & $\mathrm{NS}$ \\
5 & Knowledge about conservation & 76.92 & 23.08 & $33.92^{*}$ & 0.00 & $\mathrm{~S}$ \\
6 & Processing of wild food & 87.18 & 12.82 & $64.69^{*}$ & 0.00 & $\mathrm{~S}$ \\
7 & Effects of deforestation & 83.76 & 16.24 & $53.34^{*}$ & 0.00 & $\mathrm{~S}$ \\
8 & Knowledge about forest conservation & 97.44 & 2.56 & $105.31 *$ & 0.00 & $\mathrm{~S}$ \\
\hline
\end{tabular}

$\mathrm{s}=$ significant, $\mathrm{NS}=$ non significant 


\section{Conclusion and recommendations}

Seven types of wild resources, namely fuelwood, wild foods, thatch, timber, leaf litter, fodder and medicinal plants, were used by the respondents. The weighted dependency score identified the majority of the respondents were under category dependent followed by most dependent and somewhat dependent but minority of the respondents were under category not dependent. This dependency pattern is affected by change in total income, total land and education status of the respondents. Respondents having low total income, low education status and lesser amount of land were found to be more dependent on wild resources.

Majority of respondents were found to be knowledgeable about biodiversity, but not about wild medicinal plants and the distribution of rare wild plants. Majority of the respondents have positive attitude towards forest resource conservation. But they were found to be against the traditional mechanism of conservation. Almost all of the respondents have played significant role in conservation of wild resource.

It is strongly suggested that socially and culturally important species be promoted and their status and distribution be investigated through biophysical analysis. Since the respondents having lesser amount of land, low income and low education were found to be more dependent on wild resources, more community-oriented programmes should be initiated. Training on identification and occurrence of wild medicinal plants and rare wild resources should be imparted to young and middle aged people.

\section{References}

Baral, N. 2005. Resource Use and Conservation Attitudes of Local People in the Western Terai landscape, Nepal. M.Sc. Thesis, Florida International University, Miami, Florida, USA.

Bengwayan, A. M. 2003. Intellectual and Cultural Property Rights of Indigenous and Tribal Peoples in Asia. Minority Rights Group International, UK.
CBS. 2003. Statistical Year Book of Nepal 2003. Central Bureau of Statistics, Kathmandu, Nepal.

CBS. 2004. Statistical Year Book of Nepal 2004. Central Bureau of Statistics, Kathmandu, Nepal.

Dhungel, S. and B. Adhikari. 1994. Buffer zone vital to minimize people park conflict. In Kathmandu Post National daily Newspaper, Kathmandu, Nepal. October 30, 1994.

DNPWC. 2003. Royal Shuklaphanta Wildlife Reserve and Buffer Zone Management Plan. Department of National Parks and Wildlife Conservation, Kathmandu, Nepal.

Ellis, F. 2000. Rural Livelihoods and Diversity in Developing Countries. Oxford University Inc., New York, USA.

McLean, J., and S. Straede. 2003. Conservation, Relocation and the Paradigms of Park and People Management. A Case Study of Padampur Village. Royal Chitwan National Park, Chitwan, Nepal.

Molnar. 2006. People and Protected Areas: New Agendas for Conservation. id21 insights, pp-1. Institute of Development Studies, UK.

Pant, B. 2007. Impact of Human Relocation Program on Rural Livelihood: A Study from Shuklaphanta Wildlife Reserve, Nepal. A Report Submitted to Institute of Forestry, Pokhara, Nepal and The Rufford Maurice Laing Foundation, Rufford Small Grant for Nature Conservation, UK.

Santayana, M., Tardio, J. and Morales, R. N. 2005. The gathering and consumption of wild edible plants in the Campoo (Cantabria, Spain). International Journal of Food Sciences and Nutrition $\mathbf{5 6}$ (7): 529-542.

Sharma, S. 2006. NGOs in reshaping socioeconomic status of Tharus of dang District in Nepal. Tharu Indeginous NGOs Federation, Lalitpur, Nepal. 